\title{
VERIFYING USER IDENTITIES IN DISTANCE LEARNING COURSES: DO WE KNOW WHO IS SITTING AND SUBMITTING BEHIND THE SCREEN?
}

\author{
Karen Paullet, Robert Morris University, paullet@rmu.edu \\ David M. Douglas, Robert Morris University,paullet@rmu.edu \\ Adnan Chawdhry, California University of Pennsylvania, chawdhry_a@calu.edu
}

\begin{abstract}
The popularity of distance education is more than a transitory educational tool. It has become entwined within nearly every educational environment imaginable. Governments, businesses, and academia all employ some type of learning and testing with the current limitations of the virtual world. The attractiveness of online learning is convenience. Within these parameters of convenience are the inherent challenges of security and user identification. This exploratory study of 457 undergraduate students will assess the validation of student identities, as well as, authentication and academic integrity methods that are set in place for distance learners.
\end{abstract}

Keywords: Distance Learning, Online Learning, Student Verification

\section{INTRODUCTION}

The popularity of distance education is more than a transitory educational tool. It has become entwined within nearly every educational environment imaginable. Governments, businesses, and academia all employ some type of learning and testing with the current limitations of the virtual world. The attractiveness of online learning is convenience. Within these parameters of convenience are the inherent challenges of security and user identification. One particular area of concern is academic integrity within the confines of testing user knowledge of course material. The rising status of online education requires new user authentication parameters to preserve institutional integrity and student code of conduct credentials. How do instructors know who is being tested without an actual face-to-face interaction?

Student identification in online courses is becoming a major concern for university instructors and administrators who control the access to the learning environment. Developing an understanding and availability of identification technologies is imperative to maintaining the integrity of online education. With the increase in the popularity and availability of online education offered by colleges and universities, authentication is no longer an option as it has become essential to maintaining the integrity of the institutional credentials. In 2008, the Federal Higher Education Opportunity Act (HEOA) required educational institutions to create methods to determine that the "students of record are those actually accessing the system and taking online exams by adopting identification technologies as they become more ubiquitous" [11] as user verification is not always established.

As universities have attempted to remain competitive by offering online courses, validating student's identities have become difficult. There is no doubt that distance learning has always seen this challenge and been questioned with identifying the identity of distance education students. As a result, universities and colleges should focus on implementing verification methods to establish user identities. This study will assess the validation of student identities, as well as, authentication and academic integrity methods that are set in place for distance learners. The following research questions were explored:

RQ1: What methods and measures have been implemented to enforce academic integrity and validate user identities in distance education?

RQ2: Do Age, Gender, and Level of Education impact the resources used when taking an online class or exam? 


\section{RELATED LITERATURE}

Academic dishonesty is an area of concern for both brick-and-mortar and online academic instructions. In traditional classrooms, faculty can usually monitor student's activities where they are able to put a face to an actual student. As of May 2014, there are approximately, 5.5 million students who took at least one online course [7]. Courses offered online pose a challenge to educators as students work independently and with very little monitoring by the instructor. Online courses appear to remove barriers of instructor observation and can provide students with an increased opportunity to cheat [5]. According to Grijalva [4], it is often believed that since students and faculty do not interact face-to-face in most online classes that students will engage in a higher number of cheating incidents than students attending traditional classes.

The validation of student's identities has been questioned by those critical of distance learning [1]. Do educators really know who has completed the course requirements in online classes is a question of debate. The College of Opportunity and Affordability Act (H.R. 4137), "requires institutions that offer distance education to have processes through which the institution establishes that the student who registers in a distance education course or program is the same student who participated in and completes the program and receives the academic credit" [3]In order to maintain the integrity of online learning, validating the end users identity is a priority.

According to Bunn, Caudill and Gropper, [2], it is believed that students cheating behavior can be broken down into two categories. The first is planned cheating which can involve using notes, copying homework, and plagiarizing. Students should be aware that what they are doing is wrong. The second is panic cheating, which can happen when a student is in the middle of taking an exam. While taking the exam they realize that they are not prepared and look over at another students work for answers. In online courses, planned cheating might be more common than panic cheating due to the nature of the online environment [4]. When taking an exam online, students can search for answers online or through the course textbook, by asking a friend for help or they might have another person take the exam.

One of the reasons why students cheat in online classes might be because students do not understand what constitutes cheating. In some online classes the course expectations and requirements have not been implemented or discussed. A 2011 study in regard to cheating online reported that $75 \%$ of students reported cheating when taking online quizzes and exams [9]. When faculty implemented honor codes or academic integrity policies, this number decreased significantly because students believed that they were being held accountable for their actions.

A study conducted by Grijalva, Kerkvliet, and Nowell [4], examined the level of cheating in online courses. The researchers used class cheating and testing policies to examine student responses. The findings revealed that academic dishonesty in a single online class is no more prevalent than in traditional classrooms. Throughout education, students have always come up with excuses as to why their assignments are late. A familiar reason is "the dog ate my homework." In 2014, living in a world surrounded by technology, student excuses have changed. We now hear, "the dog ate my flashdrive," "the Internet connectivity dropped while I was taking an exam," or "my computer has a virus." Technology has provided students with new opportunities for academic dishonesty. Students can now search the Internet while taking an online exam, or use thoughts and references of published authors as their own during an exam or when completing assignments [13]. The ease of cheating and plagiarism in online courses is less visible to their classmates and instructors.

Students are now using new methods to cheat online. Krask [8] provides an example where a student starts an exam so that they are able to view all of the questions. The questions are then printed so that the student has time to search for the answers. After printing the questions, the student then disconnects from the Internet which will cause the exam to lock, which in turn does not permit the student to enter the exam to finish. After searching for answers, the student emails the instructor, often times providing a screen shot of the connection loss from the Internet, and requests for the exam to be reset [14]. Some students that have previously taken the exam save copies to give to their friends or post the questions on sites such as Course Hero and Koofers which are considered tutoring sites where students can often times review past exams, assignments and projects used in their current courses. 


\section{PREVENTATIVE MEASURES}

Pencil and paper testing are fast becoming antiquated and displaced by the growing trend of testing inside an online environment. One of the first concerns in accessing any website is the security of the site and user verification. User names and passwords are used as a security verification process for accessing accounts online. Even though technology can provide students opportunities for academic dishonesty, it can also provide ways to monitor and control these opportunities [10]. When designing an exam, instructors have the ability to use a lockdown browser. A lockdown browser, such as Respondus, will not allow students to search the Internet during the exam from the computer that they are using. This method can help eliminate cheating by making the students aware that searching for answers while taking the exam is unacceptable. The reality is that the lockdown browser can become inefficient very quick since many students use and own multiple devices such as a Smartphone or tablet which would enable them to search elsewhere.

Educational accrediting bodies are beginning to require institutions to provide documentation on how they are verifying student identities in distance learning classes to ensure academic integrity [6]. User verification strategies must be integrated in order to establish student's identities. Some faculty members require the students to use a webcam when taking an exam so that they can see who is taking the test. In order for this to be valid, the instructor would need to have met the student or require each student to scan their student identification for verification.

Educators with distance learning students are confronted with a crucial issue, determining the identity of the participant. This moves to the "front and center' of the classroom experience during testing and determining the originator of written exams. Moreover, determining user identity in the virtual classroom is also linked to user progress and student aid eligibility. Student aid eligibility; of course, is linked to students meeting the minimum institutional academic requirements. To help validate student identities, keystroke dynamics are beginning to be used. Keystroke dynamics is a process that scrutinizes a user's typing style at their terminal keyboard by monitoring "keyboard inputs thousands of times per second in an attempt to identify users based on habitual typing rhythm patterns [12]. "Keystroke dynamics is not what you type, but how you type" [12]. Existing evidence demonstrates the reliability of keystroke rhythm to accurately determine user identity. Keystroke dynamics is inexpensive versus other biometric systems. A keyboard is the only necessary hardware that is used [12].

There are two keystroke verification techniques, static or continuous. Static verification only works at specific time intervals. These intervals could occur at login or specific times. A major weakness in this technique is that it does not provide uninterrupted security after the initial verification process has occurred. Conversely, continuous verification monitors the typing behavior of the user throughout the interaction process. Continuous keystroke monitoring can be an important tool in restrictive access environments and where alertness is crucial such as air traffic control. Keystroke recognition can detect fatigue and drowsiness and alert third parties or automated monitoring systems [12]

Biometric identification techniques are inherently designed to recognize particular characteristics of our bodies and our behavior. Behavioral and body dynamic changes although slight are inevitable. For that reason, biometric technologies require a robust environment in which to operate and allow for technological advances to be integrated into the identification and verification process systems [12]. As the cost of online identification and verification, more sophisticated systems can be integrated into the process. Some suggestions include: hand geometry detection, thumb print readers, retina scans or thermal imagery of the face via web cameras, or voice recognition software. The downside of biometrics is that it is extremely expensive [12].

\section{METHODOLOGY}

With the advent of newer technologies to support distance education in the academic environment, universities need to evaluate academic integrity, how they validate student identities in distant education, and what administrators and faculty members do to authenticate student identities. However, the convenience that distance education provides educators, administrators, and students sometimes overshadows the need to enforce student identities and academic integrity, which could potentially introduce the risk of having another student complete classroom assignments in place of the one registered for the course. The study explores the following two research questions: 
RQ1: What methods and measures have been implemented to enforce academic integrity and validate user identities in distance education?

RQ2: Do Age, Gender, and Level of Education impact the resources used when taking an online class or exam?

The study examined students at two small mid-Atlantic Universities during the month of April 2014. The research utilized a quantitative methodology to assess the methods used to understand academic integrity, validate student identities, and provide measures so that universities can implement to better validate student identities. The population chosen for this study was comprised of undergraduate and graduate students enrolled in on-campus and online programs of study. Undergraduate students and graduate students were surveyed in order to gather data from students 18 years of age and older. A total of 457 respondents completed the survey. The survey was designed to obtain information on the respondents' experience with online distance education classes, how they completed their coursework, and if they ever allowed others to complete work on their behalf. Additionally, the survey addressed methods, if any, used to validate student identities in their online courses. The survey was conducted using Survey Monkey, an online tool, to gather and organize data. The data was imported into SPSS for further analysis. This study used Chi-square with a statistical significance at the .05 margin of error with a $95 \%$ confidence level. The study was a convenience sample surveying students from all departments within the university which included the School of Arts and Humanities, Business, Science and Math, Engineering, Computer Science, Information Technology, Criminal Justice and Psychology.

The survey instrument consisted of 18 closed-ended questions and two open ended questions for further understanding of participant comments and responses. The first three questions focused on student demographics; which included gender, age, and education level. Questions 4 through 18 asked students if they completed an online course, methods used for student validation, tools / external sources used to complete assignments and exams, their ethical opinion of utilizing external sources measured through 5 choices (Strongly Agree, Somewhat Agree, Neutral, Somewhat Disagree, Strongly Disagree), and their self-assessment of their own personal philosophy when completing online course work. The final two questions asked the students of methods they felt could be implemented in an effort to validate student identities and any additional comments they may have about the topic.

\section{RESULTS}

The survey responses were analyzed at both universities and recorded as either University A or University B. University A had students ranging from 18 years of age to 63 years and University B had students ranging from 18 to 47 years of age. Similarly, the study determined that University A had approximately $33.5 \%$ Male students and $66.5 \%$ female students. University B had a similar distribution with $41.4 \%$ Males and $58.6 \%$ females.

The next set of questions determined if students had taken online classes and if so, were authentication methods such as Skype or Biometrics used to validate a student's identity. It is important to note that if students responded "No" to taking an online class, the survey immediately concluded. Both universities had a strong response rate of students who took at least one online class. University A had a $94.2 \%$ response rate of students who took at least one online class while University B had an $87.5 \%$ response rate of students who took at least one online class. A complete breakdown of these responses can be found in Table 1 .

Table 1: At Least One Online Class

\begin{tabular}{|lrr|}
\hline $\begin{array}{l}\text { Taken Online } \\
\text { Class }\end{array}$ & $\begin{array}{r}\text { University A } \\
\text { Yes }\end{array}$ & $\begin{array}{r}\text { University B } \\
\hline \text { No }\end{array}$ \\
\hline & $5.80 \%$ & $87.50 \%$ \\
\hline & $100.00 \%$ & $12.50 \%$ \\
\hline
\end{tabular}


Once it was determined if the students had taken at least one online class, they were asked about methods adopted within the course to help identify if tools were used to validate student identities and measure academic integrity. A summary of each response is detailed in Tables 2 and 3. University A respondents found that a majority did not utilize authentication methods or exam proctors. However, $31.45 \%$ of the students did claim they read the Academic Integrity policy for the university. University B found that $88.9 \%$ of the respondents utilized Exam Proctors for their online exam and approximately $29.63 \%$ read the academic integrity policy. However, only $1.85 \%$ responded that some authentication method was used to validate the student identity in their online course. Additional statistics for the authentication methods can be found in Tables 2 and 3 for University A and University $\mathrm{B}$, respectively.

Table 2: University A Authentication Methods

University A

\begin{tabular}{|lccc|}
\hline & $\begin{array}{c}\text { Authentication } \\
\text { Method Used }\end{array}$ & $\begin{array}{c}\text { Academic } \\
\text { Integrity Policy }\end{array}$ & $\begin{array}{l}\text { Exam } \\
\text { Proctor }\end{array}$ \\
\hline Yes & $11.84 \%$ & $31.45 \%$ & $11.29 \%$ \\
\hline No & $88.16 \%$ & $68.55 \%$ & $88.71 \%$ \\
\hline & $100.00 \%$ & $100.00 \%$ & $100.00 \%$ \\
\hline
\end{tabular}

Table 3: University B Authentication Methods

\begin{tabular}{|lccc|}
\multicolumn{4}{|c}{ University B } \\
\hline & $\begin{array}{c}\text { Authentication } \\
\text { Method Used }\end{array}$ & $\begin{array}{c}\text { Academic } \\
\text { Integrity Policy }\end{array}$ & $\begin{array}{l}\text { Exam } \\
\text { Proctor }\end{array}$ \\
\hline Yes & $1.85 \%$ & $29.63 \%$ & $88.89 \%$ \\
\hline No & $98.15 \%$ & $70.37 \%$ & $11.11 \%$ \\
\hline & $100.00 \%$ & $100.00 \%$ & $100.00 \%$ \\
\hline
\end{tabular}

Another set of questions aimed at determining resources used by students at both universities including working in groups, having others complete assignments or discussion questions, and using external sources for an online class or online exam. For both universities, the students responded with less than $4 \%$ stating that they rarely used others to complete their assignments or discussion questions. The majority of students at both universities responded that they used external sources in their online class with University A reporting $76.66 \%$ and University B reporting $92.45 \%$. University A also reported that $47.34 \%$ of the students used external sources during their online exam and $55.56 \%$ reported the same at University B. Lastly, $31.45 \%$ of the students at University A reported that they worked in groups while completing their work online and University B reported $27.78 \%$ for the same category. A summary of these questions is provided in Tables 4 and 5.

Table 4: University A: Using External Resources for Class

\begin{tabular}{|rrrrr|r|}
\hline & $\begin{array}{l}\text { Worked In } \\
\text { Group / } \\
\text { Friend }\end{array}$ & $\begin{array}{l}\text { Others } \\
\text { Complete } \\
\text { Assignments }\end{array}$ & $\begin{array}{l}\text { Others } \\
\text { Complete } \\
\text { DQ }\end{array}$ & $\begin{array}{l}\text { External } \\
\text { Sources } \\
\text { Online } \\
\text { Class }\end{array}$ & $\begin{array}{l}\text { External } \\
\text { Sources } \\
\text { Online } \\
\text { Exam }\end{array}$ \\
\hline Yes & $31.45 \%$ & $3.76 \%$ & $2.19 \%$ & $76.66 \%$ & $47.34 \%$ \\
\hline No & $68.55 \%$ & $96.24 \%$ & $97.81 \%$ & $23.34 \%$ & $52.66 \%$ \\
\hline & $100.00 \%$ & $100.00 \%$ & $100.00 \%$ & $100.00 \%$ & $100.00 \%$ \\
\hline
\end{tabular}


Table 5: University B: Using External Resources for Class

\begin{tabular}{|rrrrrr|}
\hline & \multicolumn{1}{|l}{$\begin{array}{l}\text { Worked In } \\
\text { Group / } \\
\text { Friend }\end{array}$} & $\begin{array}{l}\text { Others } \\
\text { Complete } \\
\text { Assignments }\end{array}$ & $\begin{array}{l}\text { Others } \\
\text { Complete } \\
\text { DQ }\end{array}$ & $\begin{array}{l}\text { External } \\
\text { Sources } \\
\text { Online } \\
\text { Class }\end{array}$ & $\begin{array}{l}\text { External } \\
\text { Sources } \\
\text { Online } \\
\text { Exam }\end{array}$ \\
\hline Yes & $27.78 \%$ & $3.70 \%$ & $1.85 \%$ & $92.45 \%$ & $55.56 \%$ \\
\hline No & $72.22 \%$ & $96.30 \%$ & $98.15 \%$ & $7.55 \%$ & $44.44 \%$ \\
\hline & $100.00 \%$ & $100.00 \%$ & $100.00 \%$ & $100.00 \%$ & $100.00 \%$ \\
\hline
\end{tabular}

The study asked the students about methods they may have used to complete their online exams, which includes their mobile phones, a copy of the exam, another person taking the exam, internet searches, and using websites with older exams. For both universities, the highest response was with Internet searches where University A reported $19.08 \%$ and University B reported $39.06 \%$. A close second response was the use of Mobile Phones with University A reporting $17.3 \%$ and University B reporting $32.81 \%$. At both universities, the least used method was a Copy of an Exam with a response rate of $1.27 \%$ for University A and 3.13\% for University B. A summary breakdown of these responses is provided in Table 6.

Table 6: Methods to Assist in Taking an Online Class

\begin{tabular}{|lrrrrr|}
\hline & \multicolumn{3}{c}{ University A } & \multicolumn{3}{c}{ University B } \\
\hline Yes & \multicolumn{2}{c}{ No } & \multicolumn{3}{c|}{ No } \\
\hline Mobile Phone & $17.30 \%$ & $82.70 \%$ & $32.81 \%$ & $67.19 \%$ \\
\hline Copy of Exam & $1.27 \%$ & $98.73 \%$ & $3.13 \%$ & $96.88 \%$ \\
\hline Another Person Take Exam & $4.33 \%$ & $95.67 \%$ & $6.25 \%$ & $93.75 \%$ \\
\hline Internet Searches & $19.08 \%$ & $80.92 \%$ & $39.06 \%$ & $60.94 \%$ \\
\hline Website with past Exams & $5.60 \%$ & $94.40 \%$ & $9.38 \%$ & $90.63 \%$ \\
\hline
\end{tabular}

Lastly, it was important to evaluate the respondents' ages, gender, and level of education against working in groups, methods used to take an exam, using external resources, and reading the code of conduct to determine any statistical significance. The study found relationships to be statistically significant if they had a value less than $5 \%$ or .05 . When looking at age compared to these variables, University A found statistical significance between working in groups, using a mobile phone when taking an exam, conducting Internet searches, and assistance from external sources. However, University B only found that Internet searches showed a statistical significance with Internet searches. Unfortunately, neither of the two universities found a statistical significance between the variables and gender. The last analysis looked at the level of education in comparison to the above mentioned variables. University A found that working in groups, websites with old exams, using another person to complete assignments, using another person to complete discussion board, reading the code of conduct, and assistance from external sources. University B had all of the same points being statistically significant with the exception of websites with old exams. The complete list of values can be found in Tables $7-9$. 
Table 7: Statistical Significance for Age

\begin{tabular}{|c|c|c|c|c|c|c|}
\hline \multirow[b]{2}{*}{ Age } & \multicolumn{3}{|c|}{ University A } & \multicolumn{3}{|c|}{ University B } \\
\hline & $\begin{array}{l}\text { Chi } \\
\text { Square } \\
\text { Value }\end{array}$ & $\begin{array}{l}\text { Degree of } \\
\text { Freedom }\end{array}$ & $\begin{array}{l}\text { Significance } \\
\text { Level }\end{array}$ & $\begin{array}{l}\text { Chi } \\
\text { Square } \\
\text { Value }\end{array}$ & $\begin{array}{l}\text { Degree of } \\
\text { Freedom }\end{array}$ & $\begin{array}{l}\text { Significance } \\
\text { Level }\end{array}$ \\
\hline Worked in Group & 66.648 & 18 & .000 & 11.314 & 10 & .334 \\
\hline \multicolumn{7}{|l|}{ Methods to Take Exam } \\
\hline Used Mobile Phone & 25.273 & 9 & .003 & 5.874 & 5 & .319 \\
\hline Copy of Exam & 6.090 & 9 & .731 & 1.323 & 5 & .933 \\
\hline Other Taking Exam & 8.989 & 9 & .438 & 3.085 & 5 & .687 \\
\hline Internet Searches & 25.154 & 9 & .003 & 13.601 & 5 & .018 \\
\hline $\begin{array}{l}\text { Websites With Old } \\
\text { Exams }\end{array}$ & 11.254 & 9 & .259 & 7.624 & 5 & .178 \\
\hline $\begin{array}{l}\text { Other Person Complete } \\
\text { Assignments }\end{array}$ & 24.304 & 18 & .145 & 4.351 & 10 & .930 \\
\hline $\begin{array}{l}\text { Other Person Complete } \\
\text { Discussions }\end{array}$ & 21.149 & 18 & .272 & 4.351 & 10 & .930 \\
\hline Read Code of Conduct & 26.104 & 18 & .097 & 11.485 & 10 & .321 \\
\hline $\begin{array}{l}\text { Assistance from External } \\
\text { Sources }\end{array}$ & 29.440 & 18 & .043 & 17.495 & 10 & .064 \\
\hline
\end{tabular}

Table 8: Statistical Significance for Gender

\begin{tabular}{|c|c|c|c|c|c|c|}
\hline \multirow[b]{2}{*}{ Gender } & \multicolumn{3}{|c|}{ University A } & \multicolumn{3}{|c|}{ University B } \\
\hline & $\begin{array}{l}\text { Chi } \\
\text { Square } \\
\text { Value }\end{array}$ & $\begin{array}{l}\text { Degree of } \\
\text { Freedom }\end{array}$ & $\begin{array}{l}\text { Significance } \\
\text { Level }\end{array}$ & $\begin{array}{l}\text { Chi } \\
\text { Square } \\
\text { Value }\end{array}$ & $\begin{array}{l}\text { Degree of } \\
\text { Freedom }\end{array}$ & $\begin{array}{l}\text { Significance } \\
\text { Level }\end{array}$ \\
\hline Worked in Group & 5.359 & 4 & .252 & 6.989 & 4 & .136 \\
\hline \multicolumn{7}{|l|}{ Methods to Take Exam } \\
\hline Used Mobile Phone & .676 & 2 & .713 & 1.024 & 2 & .599 \\
\hline Copy of Exam & .122 & 2 & .941 & 1.507 & 2 & .471 \\
\hline Other Taking Exam & .225 & 2 & .894 & .204 & 2 & .903 \\
\hline Internet Searches & .735 & 2 & .693 & .679 & 2 & .712 \\
\hline $\begin{array}{l}\text { Websites With Old } \\
\text { Exams }\end{array}$ & 2.980 & 2 & .225 & .317 & 2 & .854 \\
\hline $\begin{array}{l}\text { Other Person Complete } \\
\text { Assignments }\end{array}$ & 2.249 & 4 & .690 & 6.972 & 4 & .137 \\
\hline $\begin{array}{l}\text { Other Person Complete } \\
\text { Discussions }\end{array}$ & 4.461 & 4 & .347 & 7.789 & 4 & .100 \\
\hline Read Code of Conduct & 3.588 & 4 & .465 & 7.221 & 4 & .125 \\
\hline $\begin{array}{l}\text { Assistance from External } \\
\text { Sources }\end{array}$ & 3.204 & 4 & .524 & 7.085 & 4 & .131 \\
\hline
\end{tabular}


Table 9: Statistical Significance for Level of Educations

\begin{tabular}{|c|c|c|c|c|c|c|}
\hline \multirow[b]{2}{*}{ Level of Education } & \multicolumn{3}{|c|}{ University A } & \multicolumn{3}{|c|}{ University B } \\
\hline & $\begin{array}{l}\text { Chi } \\
\text { Square } \\
\text { Value }\end{array}$ & $\begin{array}{l}\text { Degree of } \\
\text { Freedom }\end{array}$ & $\begin{array}{l}\text { Significance } \\
\text { Level }\end{array}$ & $\begin{array}{l}\text { Chi } \\
\text { Square } \\
\text { Value }\end{array}$ & $\begin{array}{l}\text { Degree of } \\
\text { Freedom }\end{array}$ & $\begin{array}{l}\text { Significance } \\
\text { Level }\end{array}$ \\
\hline Worked in Group & 35.994 & 10 & .000 & 24.471 & 6 & .000 \\
\hline \multicolumn{7}{|l|}{ Methods to Take Exam } \\
\hline Used Mobile Phone & 6.252 & 5 & .282 & 1.689 & 3 & .639 \\
\hline Copy of Exam & 3.139 & 5 & .679 & 1.175 & 3 & .759 \\
\hline Other Taking Exam & 2.032 & 5 & .845 & 2.577 & 3 & .462 \\
\hline Internet Searches & 4.875 & 5 & .431 & 1.707 & 3 & .635 \\
\hline $\begin{array}{l}\text { Websites With Old } \\
\text { Exams }\end{array}$ & 14.468 & 5 & .013 & 3.239 & 3 & .356 \\
\hline $\begin{array}{l}\text { Other Person Complete } \\
\text { Assignments }\end{array}$ & 28.650 & 10 & .001 & 24.757 & 6 & .000 \\
\hline $\begin{array}{l}\text { Other Person Complete } \\
\text { Discussions }\end{array}$ & 26.685 & 10 & .003 & 25.002 & 6 & .000 \\
\hline Read Code of Conduct & 32.387 & 10 & .000 & 24.759 & 6 & .000 \\
\hline $\begin{array}{l}\text { Assistance from External } \\
\text { Sources }\end{array}$ & 23.689 & 10 & .008 & 20.017 & 6 & .003 \\
\hline
\end{tabular}

\section{DISCUSSION}

The first area of concern with online classes is validating student identities when completing online assignments and exams. This of course can be a bit more difficult to control without the use of a biometric scanners for class work and/or a webcam. From the results of the survey, it appears that the use of biometrics or webcams to validate student identities were common practice. However, some faculty did attempt to use proctors for exams so they could validate student identities in person. Regardless of how sophisticated faculty design their online courses to validate student identities, students who are motivated enough will find a way to get around each mechanism that is implemented. With that being said, it is still important to implement methods to validate student identities if nothing else but to reduce what risk already exists. For this reason, universities and faculty members could use some of the following methods to enhance their student identity validation process.

- Require the use of webcams to be used while students are logged into the class, completing online assignments, and completing online exams.

- Utilize biometrics to help identify a student's identity when they are logged in and taking the exam. In order to do this, the university must maintain a repository of the student fingerprints as they are admitted into the university to be used for student identity validation.

- Carefully read though submitted assignments to find trends that would distinguish student's submissions from previous submissions.

- Prior to starting an assignment or exam, prompt the students for responses to personal background questions that only the student would be able to answer.

- Utilize proctoring software that can track keystrokes, opening another browser, talking on the phone, and talking to someone in the room while taking an exam or logged in to complete coursework. 


\section{Issues in Information Systems \\ Volume 15, Issue I, pp. 370-379, 2014}

Before university administrators can combat academic integrity issues, they must understand the methods students use to complete online class work and determine if those methods would be acceptable to use during a student's class. Many faculty members assume that students will use external sources when completing the exam or coursework and do not implement methods to reduce the risk of students using these sources because it will take away from the convenience that online learning provides. From a student's perspective, it is very tempting to utilize shortcuts in completing work. However, many of the shortcuts will diminish the amount of knowledge and information they attain from the course content. While various students will utilize groups and external sources to help enrich the subject they are learning, others just use it to quickly complete their course work which limits the amount they learn about the course.

When designing online courses, the instructor can certainly implement methods to help reduce academic integrity issues including using a proctor for exams, having the system locking down the browser, and having students agree and sign academic dishonesty policies. This of course will align with traditional courses where students must work independently and are gauged on their own efforts. However, what if we took a different approach with online teaching and instead of implementing methods to reduce academic integrity issues; we embrace the use of groups and external sources and build our courses in such a way that they adopt those sources. Here are some examples that could be implemented:

- Restructure assignments so that they are group based assignments requiring external research for each group member.

- Structure more thought provoking exams that require students to research topics in their textbooks and online rather than simple definitional and multiple choice questions.

- Implement the need of using external sources in individual assignments.

\section{CONCLUSIONS}

As universities face trends of lower enrollment and a changing social dynamic needing flexible course delivery options, universities are inclined to offer online distant education courses to remedy the negative effects related to these trends. However, to deliver an online course compatible to a traditional one, universities must implement course content and technologies that not only engage the student but ensure academic integrity while validating student identities. From the participant responses, the universities in this study have utilized authentication methods such as biometrics, webcams / Skype, academic integrity policies, or the use of a proctor for exams. These methods can be costly and time consuming but a necessary initiative to ensure students are properly delivered course concepts. Ignoring the need for implementing these preventative measures will not only open the course to academic integrity issues but will also negatively impact the course and university's reputation causing it to be a less sought after option for higher education.

However, it is important to note that it can be difficult to combat all of the resources at a student's disposal. These would include using their mobile phone during an exam if their browser is locked down, doing internet searches to find answers to their assignments / exams, and working in groups when completing the course work. While faculty may focus on trying to mitigate the use of these resources, this study concluded an alternative thought is to encourage the use of these resources and modify your course content accordingly. Lastly, with Age being statistically significant with the use of external resources when taking an online course, faculty can assess and modify their course accordingly based upon the demographics of their online course.

\section{REFERENCES}

1. Baile, J.L., \& Jortbert, M.A. (2008). Distance learning student authentication: verifying the identity of online students. Finding Common Ground: Programs, Strategies, and Structures to Support Student Success, Vol. 3.

2. Bunn, D.N., Caudill, S.B., and Gropper, D.M. (1992). Crime in the classroom: An economic analysis of undergraduate student cheating behavior. Journal of Economic Education, 23 (Summer): 197-207.

3. Database of Federal Legislation. (2007). Higher Education Opportunity Act. Retrieved on May 4, 2014 from https://www.govtrack.us/contress/bills/110/hr4137 


\section{Issues in Information Systems \\ Volume 15, Issue I, pp. 370-379, 2014}

4. Grijalva, T., Kerkvliet, J. \& Nowell, C. (2002). Academic Honesty and Online Courses. Retrieved April 25, 2014 from http://oregonstate.edu/dept/econ/pdf/cheat.online.pap6.pdf

5. Frost, J., Hamlin, A., \& Barcyzy, C. (2007). A survey of professor reactions to scenarios of academic dishonesty in American universities. Journal of Business Inquiry: Research, Education, and Application, 6 (1), 11-18.

6. Jortbert, M. (2010). Experiences Verifying the Identity of Distance Learning Students. $26^{\text {th }}$ Annual Conference on Distance Teaching \& Learning. Retrieved on April 25, 2014 from http://www.uwex.edu/disted/conference

7. Kolowich, S. (2014, January). Exactly how many students take online courses? The Chronicle of Higher Education. Retrieved May 1, 2014 from http://chronicle.com/blogs/wiredcampus/exactly-how-manystudents-take-online-courses/49455

8. Krsak, A.M. (2007). Curbing academic dishonesty in online courses. TCC 2007 Proceedings. Retrieved on May 6, 2014 from http://etec.hawaii.edu/proceedings/2007/krsak.pdf

9. LoSchiavo, F.M., \& Shatz, M.A. (2011). The impact of an honor code on cheating in online courses. Journal of Online Learning \& Teaching. 7 (2). Retrieved on May 2, 2014 from http://jolt.merlot.org/vol7no2/loschiavo_0611.htm

10. McGee, P. (2010). Supporting Academic Honesty in Online Courses. The University of Texas. Retrieved on May 1, 2014 from http://www.thejeo.com/Archives/Volume10Number1/McGee.pdf

11. Monaco, J.V., Stewart, J.C., Cha, S-H, Tappert, C.C. (2013). Behavioral biometric verification of student identity in online course assessment and authentication of authors in literary works. IEEE $6^{\text {th }}$ International Conference of Biometrics, BTAS 2013.

12. Monrose, F., \& Rubin, A. R. (2000). Keystroke dynamics as a biometric for authentication. Future Generation Computer Systems, 16 (2000) 351-359

13. Rogers, C.F. (2006). Faculty perceptions about e-cheating during online testing. Journal of Computing Sciences in Colleges, 22(2), 206-212

14. Rowe, N.C. (2004). Cheating in Online Student Assessment: Beyond Plagiarism. On-line Journal of Distance Learning Administration 7(2). Retrieved April 30, 2014 from http://www.westga.edu/\%7edistance/ojdla/summer72/rowe72.html 